\title{
Kesiapan Menikah Perempuan Emerging Adulthood Etnis Arab
}

\author{
Nurlita Endah Karunia, Salsabilah, Sri Wahyuningsih \\ Universitas Surabaya, Jl. Raya Kali Rungkut, Surabaya \\ e-mail: nurlita@staff.ubaya.ac.id
}

\begin{tabular}{|c|c|}
\hline Abstract / Abstrak & Keywords / Kata kunci \\
\hline $\begin{array}{l}\text { Emerging adult from Arabic-Muslim families, have fulfilled expectations of their } \\
\text { families to married immediately. Marriage readiness are needed to evaluate the } \\
\text { degree of readiness into marriage life The aim of this study is to explore } \\
\text { marriages readiness of emerging adult in Arabic culture. Data were collected } \\
\text { from } 118 \text { women between } 18-25 \text { years old. Most of participants have high } \\
\text { degree of marriage readiness. In addition, most of participants have greater } \\
\text { readiness based on several criteria: moral, contextual-social, and marital-life } \\
\text { skilsl. The other hands, participants evaluated their readiness quite well on } \\
\text { financial and emotional criteria. The results indicate that social-cultural, religion, } \\
\text { and emotional maturity factors became basic evaluation of marriage readiness in } \\
\text { emerging adult. }\end{array}$ & $\begin{array}{l}\text { Marriage Readiness } \\
\text { Emerging Adult } \\
\text { Women }\end{array}$ \\
\hline $\begin{array}{l}\text { Perempuan Emerging adult beretnis Arab menghadapi harapan dari keluarga } \\
\text { untuk dapat segera menikah. Kesiapan menikah diperlukan untuk menghadapi } \\
\text { kesiapan dalam memasuki kehidupan perkawinan. Penelitian ini merupakan } \\
\text { penelitian eksploratif untuk mengetahui kesiapan menikah pada perempuan } \\
\text { emerging adult yang beretnis Arab. Berdasarkan } 118 \text { partisipan diketahui bahwa } \\
\text { mayoritas memiliki tingkat kesiapan menikah yang tergolong tinggi. Secara lebih } \\
\text { khusus, ada beberapa kriteria yang dirasakan sangat siap oleh partisipan yaitu } \\
\text { kriteria moral, kontekstual, serta menjalankan peran dalam kehidupan perkawinan. } \\
\text { Kriteria emosi serta finansial merupakan kirteria yang dinilai masih tergolong } \\
\text { cukup siap oleh partisipan. Hasil penelitian ini menyimpulkan bahwa faktor } \\
\text { sosial, budaya, agama serta kematangan emosi turut menjadi dasar penilaian } \\
\text { individu dalam menilai kriteria kesiapannya dalam menikah. }\end{array}$ & $\begin{array}{l}\text { Kesiapan Menikah } \\
\text { Emerging Adulthood } \\
\text { Perempuan }\end{array}$ \\
\hline
\end{tabular}

\section{Pendahuluan}

Keluarga etnis Arab pada umumnya menikahkan anak perempuannya ketika sudah menyelesaikan pendidikan tingkat Sekolah Menengah Atas (SMA) sekitar usia 18 tahun. Menurut Asmita (2014) perempuan beretnis Arab di Indonesia rata-rata menikah pada usia emerging adulthood (Balfas \& Ratriana, 2015). Keluarga etnis Arab di Indonesia memiliki budaya kolektif. Ada ikatan yang kuat di antara anggota keluarga inti (nuclear family) bahkan keluarga besar (extended family). Biasanya orang tua sudah menentukan jodoh anaknya sebelum individu tersebut lulus, sehingga ketika sudah lulus maka akan segera dinikahkan. Penelitian Bejanyan, Marshall, dan Ferenczi (2014) menunjukkan bahwa pada budaya kolektif, orang tua memiliki pengaruh yang besar pada pemilihan pasangan anak-anaknya, termasuk dalam keputusan untuk menikah.

Keputusan menikah pada perempuan beretnis Arab yang berusia sekitar 18-25 tahun di Indonesia, salah satunya juga dipengaruhi oleh orang tua. Hal tersebut dilakukan oleh orang tua dikarenakan suatu tradisi turuntemurun dari nenek moyang yang menikah di usia muda serta tradisi menikah dengan sesama suku. Penelitian yang dilakukan Montazeri, Gharacheh, Mohammadi, Rad, dan Ardabili (2016) di Iran menunjukkan bahwa orang tua cenderung untuk segera menikahkan anaknya. Hal ini dilakukan atas dasar keyakinan agama yang diyakini. Dalam ajaran agama Islam diketahui bahwa individu dianggap telah menyempurnakan sebagian dari agamanya 
dengan menikah (Montazeri, Gharacheh, Mohammadi, Rad, \& Ardabili,2016).

Seiring berkembangnya waktu, perempuan yang berusia 18 tahun ke atas sudah memiliki pemikiran yang berbeda dari generasi sebelumnya. Sebagian dari mereka mengatakan siap untuk menikah pada usia tersebut dengan tujuan untuk menghindari relasi berpacaran, sesuai dengan pemahaman individu akan ajaran agama yang dimilikinya. Hal ini sejalan dengan penelitian Fuller, Frost, dan Burr (2015) yang menunjukkan bahwa religiusitas memiliki hubungan dengan usia harapan menikah pada individu. Namun penelitian lain menunjukkan hasil yang berbeda. Adanya kesempatan pendidikan dan pekerjaan yang lebih luas terkait dengan gender, membuat usia perkawinan menjadi meningkat (Geist, 2017). Laki-laki dan perempuan sama-sama memiliki kesempatan untuk menyelesaikan pendidikan dan berkarir sehingga menunda untuk menikah. Beberapa perempuan beretnis Arab mengatakan tidak siap untuk menikah pada usia emerging adult dikarenakan masih terlalu muda untuk menjalani kehidupan pernikahan. Perempuan beretnis Arab di generasi sekarang memandang bahwa kesiapan sebelum menikah sangatlah penting, baik secara finansial maupun secara psikologis. Hasil temuan El-Mubarak dan Ogunbad (2017), menunjukkan bahwa Muslim di Malaysia cenderung menunda usia menikah dengan pertimbangan kesiapan secara finansial, psikologis dan kesiapan menghadapi tanggung jawab dalam perkawinan.

Kesiapan menikah menurut Duvall dan Miller (1985) adalah bentuk kesediaan individu dalam menjalani hubungan dengan pasangannya, menerima tanggung jawab baru dalam hubungan suami atau istri, terlibat dalam hubungan seksual, mengatur keluarga baik suami atau istri, serta mengasuh anak. Sedangkan, menurut Larson dan Thayne (1998) kesiapan menikah dipandang sebagai cara individu mengevaluasi diri untuk siap menghadapi tantangan pernikahan dan dapat mengambil tanggung jawab. Oleh karena itu, perlu adanya pertimbangan terlebih dahulu sebelum individu memutuskan untuk siap menikah. Mengingat tuntutan yang harus dihadapi setelah menikah akan lebih berat.

Beberapa aspek dalam kesiapan menikah menurut hasil penelitian Ghalili, Etemadi, Ahmadi, Fatehizadeh \& Abedi (2012) diketahui beberapa kriteria atau aspek kesiapan menikah yaitu kesiapan usia (usia yang dianggap layak untuk menikah), kesiapan fisik (kemampuan untuk melakukan hubungan seksual bagi lakilaki dan kemampuan untuk melahirkan bagi perempuan), kesiapan mental (menekankan pada kemampuan membuat rencana masa depan dan mengambil keputusan), kesiapan finansial (kemampuan untuk menghidupi keluarga), kesiapan moral (berisi nilai budaya dan agama yang dipegang teguh), kesiapan emosi (kesiapan untuk mengontrol diri), kesiapan kontekstual-sosial (kesiapan yang didasarkan pada konteks sosial), kesiapan secara interpersonal (kesiapan dalam memahami orang lain, saling terbuka serta menghormati adanya perbedaan), dan kesiapan peran (peran baru sesuai peran dalam kehidupan pernikahan).

Masa emerging adulthood adalah masa individu yang ditandai dengan berlangsungnya proses transisi perubahan dari remaja menuju ke dewasa. Masa ini tergolong dalam masa yang ditandai dengan individu mulai bereksplorasi dalam hal percintaan yang menjadi lebih intim dan serius. Biasanya pada usia remaja saat berpacaran mereka menjalani hubungan dengan bersenang-senang dan berkencan (Padgham \& Blyth, 1991 dalam Arnett 2000).

Masa emerging adulthood beberapa individu sedang menyiapkan dirinya untuk memasuki kehidupan pernikahan. Menurut Arnett (2000) pada usia ini individu mengalami proses penundaan sebagai orang tua dikarenakan masih pada masa bereksplorasi dalam hal percintaan. Namun berbeda pada perempuan emerging adult keturunan Arab, yang secara konteks budaya-agama memiliki harapan dari orang tuanya untuk segera menikah (Montazeri, Gharacheh, Mohammadi, Rad, dan Ardabili; 2016). Oleh karena itu, individu yang memutuskan untuk menikah di usia emerging adulthood maka diperlukan 
adanya kesiapan pada dirinya untuk menghadapi kehidupan pernikahan.

Penelitian ini bertujuan untuk mengetahui bagaimana kesiapan menikah pada perempuan emerging adult yang beretnis Arab. Hasil penelitian ini diharapkan mampu memetakan kriteria-kriteria kesiapan menikah pada perempuan emerging adult yang beretnis Arab sehingga dapat dijadikan landasan dalam penentuan usia dan persiapan yang diperlukan untuk mempersiapkan kehidupan perkawinan.

\section{Metode}

Penelitian ini merupakan deskriptif exploratory untuk memetakan kesiapan menikah pada perempuan emerging adult bertenis Arab. Penelitian ini melibatkan sejumlah 118 partisipan perempuan dengan rentang 18 hingga 25 tahun. Partisipan saat ini berstatus mahasiswa (55.9\%), bekerja (27.1\%) dan tidak bekerja (17\%).

Teknik sampling yang digunakan adalah snowball sampling dengan cara menghubungi salah satu partisipan yang menjadi informan utama. Informan utama kemudian mengarahkan pada partisipan lainnya yang sesuai dengan karakteristik yang diharapkan (Neuman, 2003).

Penelitian ini adalah penelitian survei dengan menggunakan angket dalam pengumpulan datanya. Data-data yang terdapat pada penelitian ini diperoleh dengan menggunakan angket yang terbagi menjadi dua bagian, yaitu angket terbuka dan angket tertutup. Angket terbuka terdiri atas dua jenis bagian, yang pertama data demografis yang digunakan untuk memperoleh data diri subjek (seperti usia, status pekerjaan, pendidikan terakhir, aktivitas saat ini) dan beberapa pertanyaan terbuka untuk mengungkap kondisi hubungan relasi dengan lawan jenis, sikap terhadap perkawinan dan perkawinan usia muda. Bagian kedua angket terbuka ditujukan untuk menggambarkan kesiapan menikah.
Kesiapan menikah merupakan sebuah evaluasi terkait dengan kesediaan individu dalam mempersiapkan dirinya guna untuk menghadapi tantangan pernikahan serta dapat mengambil tanggung jawab dalam menjalankan segala peran barunya sebagai istri maupun orang tua. Pada variabel ini alat ukur akan disusun oleh peneliti dengan menggunakan aspek dari kesiapan menikah oleh Ghalili et al (2012) terdiri dari kesiapan dalam usia, kesiapan secara fisik, kesiapan secara mental, kesiapan secara finansial, kesiapan secara moral, kesiapan secara emosi, kesiapan secara kontekstual-sosial, kesiapan secara interpersonal, dan kesiapan menjalankan peran. Semakin tinggi nilai skor dari alat ukur kesiapan menikah, maka semakin tinggi pula kesiapan yang dimiliki individu untuk menikah. Angket kesiapan berisi 28 item dengan skala respon pengukuran menggunakan likert yaitu 1 (Sangat Tidak Siap), 2 (Tidak Siap), 3 (Cukup Siap), 4 (Siap), 5 (Sangat Siap).

Validitas pada penelitian ini dilakukan dengan menggunakan content validity yang diuji oleh expert judgement, yakni mengukur validitas dengan menggunakan pendapat para ahli berdasarkan teori yang digunakan pada penelitian (Neuman, 2003). Hasil uji validitas dari expert judgement menunjukkan bahwa angket yang digunakan dalam penelitian ini sudah valid dan sesuai dengan landasan teori dan budaya yang ada. Reliabilitas angket kesiapan menikah memiliki nilai Cronbach's Alpha sebesar 0.918.

Data yang telah terkumpul kemudian dianalisis secara deskriptif. Analisis deskriptif dilakukan untuk melihat rata-rata, standar deviasi serta kategori skor variabel penelitian. Data-data penelitian diolah dengan software SPSS (Statistical Package for the Social Sciences) 22.0 for Windows. 
Tabel 1

Gambaran Mayoritas Partisipan Penelitian

\begin{tabular}{lccc}
\hline \multicolumn{1}{c}{ Kategori } & Keterangan & f & $\%$ \\
\hline Usia & 21 tahun & 29 & $24,6 \%$ \\
Urutan kelahiran & Anak Tengah & 53 & $44,9 \%$ \\
Pendidikan terakhir & SMU & 101 & $85,6 \%$ \\
Aktivitas saat ini & Kuliah & 66 & $55,9 \%$ \\
& Bekerja & 32 & $27,1 \%$ \\
\hline
\end{tabular}

Tabel 2

Gambaran Hasil Angket Terbuka

\begin{tabular}{lccc}
\hline \multicolumn{1}{c}{ Kategori } & & f & $\%$ \\
\hline Kesiapan menikah saat ini & Tidak & 81 & $68,6 \%$ \\
Harapan usia menikah & $19-24$ Tahun & 59 & $72,8 \%$ \\
& $25-30$ Tahun & 22 & $27,2 \%$ \\
Adanya dorongan orang tua untuk & Tidak & 73 & $61,9 \%$ \\
menikah usia muda & Iya & 45 & $38,1 \%$ \\
Sikap terhadap menikah usia muda & Setuju & 81 & $68,6 \%$ \\
& Tidak Setuju & 37 & $31,4 \%$ \\
Kriteria yang dianggap penting & Mental & 63 & $53,4 \%$ \\
untuk persiapan pernikahan * & Moral & 50 & $42,4 \%$ \\
& Interpersonal & 41 & $34,7 \%$ \\
Kriteria yang sudah dipersiapkan & Moral & 42 & $35,6 \%$ \\
saat ini untuk menikah * & Belum ada & 31 & $26,3 \%$ \\
& Peran & 28 & $23,7 \%$ \\
Hal yang ingin diubah dalam diri & Tidak Dapat Mengontrol Diri & 34 & $28,8 \%$ \\
& Tidak Dapat Mengontrol Emosi & 28 & $23,7 \%$ \\
& Tidak Percaya Diri & 21 & $17,8 \%$ \\
\hline
\end{tabular}

*Dihitung berdasarkan jumlah jawaban/bukan subyek

Tabel 3

Skor Tingkat Kategori Kesiapan Menikah

\begin{tabular}{cccc}
\hline Kategori & Interval Nilai & $\mathrm{f}$ & $\%$ \\
\hline Sangat Tinggi (ST) & $\mathrm{X} \geq 105,00$ & 16 & $13,6 \%$ \\
Tinggi (T) & $85,00 \leq \mathrm{X}<105,00$ & 58 & $49,2 \%$ \\
Sedang (S) & $65,00 \leq \mathrm{X}<85,00$ & 37 & $31,4 \%$ \\
Rendah (R) & $45,00 \leq \mathrm{X}<65,00$ & 6 & $5,1 \%$ \\
Sangat Rendah (SR) & $\mathrm{X}<45,00$ & 1 & $0,8 \%$ \\
Total & & 118 & $100 \%$ \\
\hline
\end{tabular}

Tabel 4

Rangkuman Skor Tingkat Kategori Kriteria Kesiapan Menikah

\begin{tabular}{lccc}
\hline \multicolumn{1}{c}{ Kategori } & Keterangan & f & $\%$ \\
\hline Kriteria kesiapan dalam usia & Tinggi & 49 & $41,5 \%$ \\
Kriteria kesiapan secara fisik & Tinggi & 47 & $39,8 \%$ \\
Kriteria kesiapan secara mental & Tinggi & 51 & $43,2 \%$ \\
Kriteria kesiapan secara finansial & Sedang & 49 & $41,5 \%$ \\
Kriteria kesiapan secara moral & Sangat tinggi & 70 & $59,3 \%$ \\
Kriteria kesiapan secara emosi & Sedang & 53 & $44,9 \%$ \\
Kriteria kesiapan secara kontekstual-sosial & Sangat tinggi & 77 & $65,3 \%$ \\
Kriteria kesiapan secara interpersonal & Tinggi & 65 & $55,1 \%$ \\
Kriteria kesiapan menjalankan peran & Sangat Tinggi & 43 & $36,4 \%$ \\
\hline
\end{tabular}




\section{Hasil}

Data penelitian ini didistribusikan ke dalam 4 tabel yaitu yang berisi demografis mayoritas partisipan, deskripsi pertanyaan angket terbuka, deskripsi tingkat kesiapan menikah dan deskripsi kriteria-kriteria kesiapan menikah. Berdasarkan tabel 1 dapat diketahui bahwa mayoritas partisipan berusia 21 tahun (24.6\%), merupakan anak tengah (44.9\%), pendidikan terakhir adalah SMU $(85.6 \%)$ dan aktivitas saat ini adalah kuliah (55.9\%).

Berdasarkan tabel 2, dapat diketahui bahwa mayoritas partisipan saat ini belum siap menikah (68.6\%), memiliki harapan menikah pada usia dalam rentang 19 hingga 24 tahun (72.8\%), orang tua tidak mendorong untuk menikah di usia muda (61.9\%), memiliki sikap yang positif terhadap menikah usia muda (68.6\%). Partisipan menilai kriteria yang dianggap penting untuk kesiapan menikah adalah mental $(53.4 \%$ dari $100 \%$ partisipan), moral (42.4\% dari $100 \%$ partisipan), interpersonal (34.7\% dari $100 \%$ partisipan). Saat ini untuk memasuki kehidupan pernikahan, mayoritas partisipan sudah memersiapkan diri dalam hal moral (35.6\% dari $100 \%$ partisipan) dan peran (23.7\% dari $100 \%$ partisipan), namun masih ada partisipan yang belum memersiapkan apapun $(26.3 \%$ dari $100 \%$ partisipan). Permasalahan dalam diri yang ingin diatasi untuk menghadapi kehidupan perkawinan adalah tidak dapat mengontrol diri $(28.8 \%$ dari $100 \%$ partisipan) dan tidak dapat mengontrol emosi (23.7\% dari 100\% partisipan).

Berdasarkan tabel 3, dapat dilihat bahwa mayoritas partisipan memiliki kesiapan menikah yang tinggi (49.2\%) dan kesiapan menikah yang tergolong sedang $(31.4 \%)$.

Tabel 4 menjelaskan mengenai hasil rangkuman dari masing-masing skor tingkat kategori kesiapan menikah yang diketahui bahwa kriteria yang dianggap sangat siap oleh mayoritas partisipan adalah kriteria moral (59.3\%), kontekstual-sosial (65.3\%) dan kriteria menjalankan peran dalam kehidupan perkawinan $(36.4 \%)$.

\section{Diskusi}

Hasil penelitian terkait kesiapan menikah pada penelitian ini menunjukkan bahwa pada perempuan beretnis Arab memiliki tingkat kesiapan menikah tergolong tinggi (49.2\%) pada tabel 3. Hal ini menunjukkan bahwa mayoritas partisipan memiliki kesiapan untuk menikah yang tergolong siap atau tinggi. Bertolak belakang dengan data angket terbuka di tabel 2 yang menunjukkan bahwa mayoritas 81 partisipan $(68.6 \%)$ merasa saat ini tidak siap untuk menikah. Alasan subjek menganggap saat ini tidak siap menikah dikarenakan secara mental dan emosi belum matang serta beberapa mengatakan masih belum lulus kuliah.

Berdasarkan hasil olah data, terdapat perbedaan hasil antara angket terbuka (tabel 2) dengan angket tertutup pada kesiapan menikah (tabel 3). Hal tersebut dikarenakan partisipan mengevaluasi secara berbeda ketika dihadapkan pada evaluasi secara umum pada pertanyaan siap atau tidaknya menikah saat ini dengan pertanyan yang menuntut partisipan untuk menilai lebih detail terkait dengan masingmasing kriteria kesiapan menikah. Oleh karena itu, peneliti juga melihat tingkat kesiapan menikah subjek dari setiap aspek-aspek kesiapan menikah untuk mengetahui pada aspek bagian mana saja yang memiliki tingkat kesiapan sangat tinggi, tinggi, sedang, rendah, atau sangat rendah.

Berdasarkan tabel 4 diketahui bahwa mayoritas partisipan memiliki kesiapan menikah yang sangat siap pada kriteria moral, kontekstual-sosial serta menjalankan peran dalam kehidupan perkawinan. Tingkat kesiapan menikah partisipan dalam kriteria secara moral tergolong dalam kategori sangat tinggi (59.3\%). Hal ini sejalan dengan tabel 2 terkait dengan kriteria yang telah dipersiapkan oleh partisipan mayoritas adalah mempersiapkan moral (35.6\%). Persiapan secara moral sebelum menikah yaitu dengan memperbanyak ilmu agama, kesabaran, mendengarkan ceramahceramah mengenai kehidupan rumah tangga, dan lain sebagainya. 
Ghalili, Etemadi, Ahmadi, Fatehizadeh dan Abedi (2012) berpendapat bahwa kesiapan secara moral akan membantu individu dalam membangun kehidupan pernikahan karena terdapat nilai-nilai, budaya, dan agama yang dipegang teguh. Pada perempuan beretnis Arab hal ini sangatlah penting, karena dari faktor budaya sejak kecil sudah ditanamkan nilai-nilai agama oleh orang tuanya. Artinya, semakin tinggi kesiapan moral maka semakin tinggi kesiapan menikah pada perempuan beretnis Arab. Dari hasil penelitian Montazeri, Gharacheh, Mohammadi, Rad, dan Ardabili (2016) menunjukkan bahwa agama yang diyakini memengaruhi keputusan individu untuk menikah..

Kriteria yang juga tergolong sangat tinggi pada mayoritas partisipan penelitian adalah kriteria konstektual-sosial $(65.3 \%)$ dapat dilihat pada tabel 4. Menurut Ghalili, Etemadi, Ahmadi, Fatehizadeh \& Abedi (2012) kesiapan kontestual-sosial adalah individu dipercaya akan siap dan matang saat berada pada situasi atau waktu yang sesuai dengan konteks sosial masing-masing. Willoughby, Hall, \& Luczak (2013) menunjukkan bahwa keyakinan yang dipegang dalam sebuah lingkungan (konteks budaya) juga turut memengaruhi sikap individu dalam perkawinan. Tingkat kesiapan kontekstual-sosial sangat tinggi dikarenakan dari konteks sosial budaya etnis Arab sendiri yaitu jika perempuan sudah menyelesaikan pendidikan di tingkat SMA maka sudah dikatakan siap dan matang untuk menikah. Hal tersebut dapat dilihat dari hasil angket demografis (tabel 1) yang menunjukkan mayoritas 101 partisipan (85.6\%) pendidikan terakhirnya adalah SMA dan saat ini sedang menyelesaikan kuliah (55.9\%).

Kriteria yang juga tergolong sangat tinggi pada mayoritas partisipan penelitian adalah kriteria menjalani peran dalam kehidupan perkawinan (36.4\%) pada tabel 4. Menurut Ghalili, Etemadi, Ahmadi, Fatehizadeh \& Abedi (2012), kesiapan menjalankan peran seperti siap berperan sebagai ibu rumah tangga, mengurus anak dan suami. Pada perempuan beretnis Arab memiliki kesiapan peran sangat tinggi dikarenakan secara budaya, orang tua biasanya memberikan pembekalan terlebih dahulu sebelum anaknya menikah seperti mengurus rumah, dan lain sebagainya. Berdasarkan peran sosial, perempuan dan lakilaki memiliki peran yang berbeda dalam kehidupan pernikahan. Terutama dalam budaya Patriaki, seperti pada etnis Arab, yang lebih menekakan tanggung jawab keputusan keuangan di pihak laki-laki sedangkan perempuan lebih pada tanggung jawab pengasuhan anak. perempuan dalam menjalankan perannya (Eagly, dalam Vogel, Wester, Heesacker, Madon; 2003).

Kriteria kesiapan menikah pada perempuan emerging adult beretnis Arab yang tergolong tinggi adalah usia, fisik, mental, interpersonal. Secara kriteria secara usia, mayoritas partisipan menilai diri mereka siap atau tergolong dalam kategori tinggi (41.5\%). Hasil yang didapatkan tergolong tinggi dikarenakan subjek merasa bahwa sebenarnya usia mereka sudah dapat dikatakan ideal untuk menikah. Hal ini sejalan dengan harapan usia partisipan untuk menikah yang mayoritas berada dalam rentang 19-24 (tabel 2). Hal ini sesuai dengan penelitian terdahulu yang menunjukkan bahwa usia berpengaruh terhadap kesiapan menikah (Krisnatuti \& Oktaviani, 2010). Holman dan Li (1997) juga mengatakan bahwa salah satu faktor yang memengaruhi kesiapan menikah adalah usia.

Kedua, kriteria kesiapan secara fisik tergolong dalam kategori tinggi (39.8\%). Jika individu sudah memiliki kesiapan secara fisik yang tinggi, maka individu tersebut sudah memiliki kesiapan yang tinggi dalam melakukan hubungan seksual dengan pasangannya dan siap untuk melahirkan anak setelah menikah (Ghalili, Etemadi, Ahmadi, Fatehizadeh \& Abedi, 2012). Artinya, semakin tinggi kesiapan fisik maka semakin tinggi kesiapan menikah pada perempuan beretnis Arab.

Ketiga, kriteria kesiapan secara mental tergolong dalam kategori tinggi (43.2\%). Partisipan penelitian juga beranggapan bahwa sebelum menikah, maka perlu mempersiapkan 
mental terlebih dahulu. Hal ini dapat dilihat pada angket demografis/terbuka (tabel 2) yang menunjukkan bahwa 63 dari 118 partisipan mengatakan bahwa hal yang perlu dipersiapkan sebelum menikah adalah mental (53.4\%). Bagi individu yang memiliki kesiapan mental tinggi maka individu dapat menghadapi dan menjalankan kehidupan barunya dengan baik (Ghalili, Etemadi, Ahmadi, Fatehizadeh \& Abedi, 2012). Artinya, semakin tinggi kesiapan mental maka semakin tinggi kesiapan menikah pada perempuan beretnis Arab.

Keempat, Kriteria kesiapan secara interpersonal juga tergolong dalam kategori tinggi $(55.1 \%)$ dapat dilihat pada tabel 4. Menurut Ghalili, Etemadi, Ahmadi, Fatehizadeh \& Abedi (2012), kesiapan secara interpersonal merupakan cara individu saat berhadapan dengan orang lain dengan mendengarkan dan memahami orang lain, dapat saling terbuka, serta menghormati adanya perbedaan yang ada. Artinya, semakin tinggi kesiapan interpersonal maka semakin tinggi kesiapan menikah pada perempuan beretnis Arab.

Dalam penelitian ini juga diketahui ada kriteria-kriteria kesiapan menikah yang masih tergolong sedang, yang artinya partisipan masih mengevaluasi bahwa dirinya antara siap atau tidak siap dalam menghadapi kehidupan perkawinan. Kriteria tersebut adalah finansial dan emosional. Kriteria kesiapan menikah secara finansial pada partisipan tergolong dalam kategori sedang (41.5\%). Penjelasan akan ini dikarenakan dari 118 subjek, mayoritas masih menempuh studi (kuliah yaitu sebanyak $55.9 \%$ dan yang bekerja hanya sebanyak $27.1 \%$, dengan ragam jenis pekerjaan part-time dan full-time seperti menjaga toko orang tua, asisten make-up, online shop, dan lain-lain. Mayoritas pada partisipan yang saat ini bekerja mendapatkan penghasilan perbulan sebesar 1,500,000-3,000,000. Holman dan Li (1997) mengatakan bahwa salah satu faktor yang memengaruhi kesiapan menikah adalah pendapatan. Sedangkan, menurut Thornton semakin tinggi perempuan memiliki pendapatan maka akan menunda untuk menikah muda (Sari
\& Sunarti, 2013). Akan tetapi pada perempuan beretnis Arab, memandang finansial bukanlah suatu kesiapan yang paling utama dikarenakan dari pasangan biasanya tidak memperbolehkan untuk bekerja atau mencari penghasilan sendiri setelah menikah.

Kriteria kesiapan menikah secara emosi juga tergolong dalam kategori sedang (44.9\%). Menurut Ghalili, Etemadi, Ahmadi, Fatehizadeh, dan Abedi (2012) kesiapan secara emosi adalah individu dapat mengontrol dirinya, menghindari perilaku agresif dan kekerasan, serta dapat mengungkapkan perasaan saat berhubungan dekat. Partisipan menganggap dirinya saat ini belum siap untuk menikah dikarenakan sebagian besar subjek tersebut masih merasa belum siap untuk tidak terikat lagi dengan orang tua secara emosional. Selain itu dari angket terbuka diketahui bahwa mayoritas partisipan memiliki permasalahan yang masih ingin diubah, yaitu merasa dirinya tidak dapat mengontrol diri dan tidak dapat mengontrol emosinya.

Kematangan secara emosi diperlukan untuk menghadapi tantangan dalam kehidupan perkawinan. Adanya permasalahan yang dialami ini menjadi pertimbangan bagi partisipan ketika mengevaluasi kesiapannya dalam menikah. Kematangan emosi menjadi hal penting dalam proses pengambilan suatu keputusan bagi individu yang memutuskan untuk siap membangun kehidupan rumah tangga bersama dengan pasangannya. Individu yang memiliki emosi yang matang individu dapat mampu menghadapi kesulitan-kesulitan yang ada dalam pernikahan, menyesuaikan diri dari lingkungan, serta menimalisir adanya konflik (Rosalina \& Ekasari, 2015).

\section{Kesimpulan}

Penelitian in menunjukkan bahwa perempuan berusia 18-25 tahun (emerging Adulthood) yang beretnis Arab memiliki kesiapan menikah yang tergolong tinggi. Namun jika dilihat secara lebih detail, diketahui bahwa tidak semua kriteria dalam kesiapan menikah dirasakan atau dinilai siap oleh 
partisipan. Mayoritas partisipan merasa sangat siap pada kriteria yang memang secara agama, budaya dan Negara telah dipersiapkan sebelumnya seperti kesiapan moral, kontekstual, menjalankan peran dalam kehidupan perkawinan.

Usia partisipan yang masih tergolong pada tahapan emerging adulthood belum sepenuhnya memiliki karakteristik individu dewasa. Hal ini tercermin dari kondisi emosi mereka yang belum matang, yang terlihat belum mampu mengontrol diri dan emosi mereka. Hal ini membuat partisipan mengevaluasi dirinya belum sepenuhnya siap dalam kriteria emosi untuk kesiapan menikah. Selain itu emerging adulthood memiliki tugas perkembangan berupa eksplorasi, salah satunya pendidikan. Hal ini membuat partisipan belum sepenuhnya merasa siap secara finansial untuk menikah, karena masih fokus untuk kuliah.

\section{Saran}

Hasil penelitian menunjukkan bahwa tingkat kesiapan menikah secara emosi pada partisipan penelitian masih tergolong sedang dikarenakan subjek masih merasa belum siap untuk tidak terikat lagi dengan orang tua secara emosional jika sudah menikah. Saran yang dapat diberikan adalah agar pihak individu, keluarga, budaya serta institusi Negara memberikan pembekalan-pembekalan terkait dengan kriteria kesiapan menikah, salah satunya dalam hal kesiapan secara emosi. Mengingat kematangan emosi penting sebagai bekal dalam menghadapi tantangan dan tekanan dalam kehidupan perkawinan.

Untuk penelitian selanjutnya diharapkan ada penelitian lanjutan berkaitan dengan hubungan antara kesiapan menikah dengan faktor-faktor yang ditengarai memengaruhi kesiapan menikah, salah satunya adalah pengelolaan emosi dan religiusitas.

\section{Referensi}

Arnett, J. J. (2000). Emerging adulthood: A theory of development from the late teens through the twenties. American Psychologist, 55(5), 469-480.

Balfas, D. Z. \& Ratriana, L. (2015). Perbedaan kesiapan menikah wanita emerging adult keturunan Arab yang akan menikah dengan etnis Arab dan bukan etnis Arab. eprints.binus.ac.id/33058/1/2014-2-00002PS\%20Abstrak001.pdf

Bejanyan, K., Marshall, T. C., \& Ferenczi, N. (2014). Associations of collectivism with relationship commitment, passion, and mate preferences; Opposing roles of parental influence and family allocentrism. Journal Pone, 10(2), 1-24.

Duvall, E. M., \& Miller, B. C. (1985). Marriage and family development $\left(9^{\text {th }}\right.$ ed). New York, US: Harper and Row Publisher.

El-Mubarak, I., \& Ogunbad, A. F. (2017). Late marriage in Islam: Malaysia as a case study. International Journal of Innovative Knowledge Concepts, 5(7), 11-20

Fuller, J. N., Frost, A. M. H., \& Burr, B. K. (2015). Exploring the impact of religiosity and socioeconomic factors on perceived ideal timing of marriage in young adults. Journal of Student Research, 4(1), 120129.

Geist, C. (2017). Marriage formation in context: four decades in comparative perspective. Social Sciences, 6(9), 1-16

Ghalili, Z., Etemadi, O., Ahmadi, S.A., Fatehizadeh, M. \& Abedi, M.R. (2012). Marriage readiness criteria among young adults of Isfahan: A qualitative study. Journal of Contemporary Research in Business, 4(4), 1076-1083.

Holman, T.B., \& Li, B.D. (1997). Premarital factors influencing perceived readiness for marriage. Journal of Family Issue, 18(2), 124-144.

Krisnatuti, D. \& Oktaviani, V. (2010). Persepsi dan kesiapan menikah pada mahasiswa. Jurnal Ilmu Keluarga dan Konsumen, 4(1), 30-36.

Larson, J. H \& Thayne, T. R (1998). Marital attitudes and personal readiness for marriage of young adult children of 
alcoholics. Alcoholism Treatment Quarterly, 16(4), 59-73

Montazeri, S., Gharacheh, M., Mohammadi, N., Rad, J. A., \& Ardabili, H. E. (2016). Determinants of early marriage from married girl's perspective in Iranian setting: A qualitative study. Journal of Environmental and Public Health, 2016(1), 1-8.

Neuman, W. L. (1993). Social researchmethods: qualitative and quantitative approaches (3rd ed.). Boston: Allyn \& Bacon.

Rosalina, M. \& Ekasari, A. (2015). Pengaruh kematangan emosi dan orientasi berkarir terhadap keputusan menikah pada mahasiswi psikologi di Universitas Islam 45 Bekasi. Jurnal Soul, 8(1), 22-33.
Sari, F. \& Sunarti, E. (2013). Kesiapan menikah pada dewasa muda dan pengaruhnya terhadap usia menikah. Jurnal Ilmu Keluarga dan Konsumen, 6(3), 143-153.

Vogel, D.L., Wester, S.R., Heesacker, M., dan Madon, S. (2003). Confirming gender stereotype: A social perspective. Sex Roles, 11-12(48), 519-528.

Willoughby, B. J., Hall, S. S., \& Luczak, H. P. (2013). Marital paradigms: A conceptual framework for marital attitudes, values, and beliefs. Journal of Family Issues, 20(10), 1-25 
KESIAPAN MENIKAH PEREMPUAN EMERGING ADULTHOOD ETNIS ARAB 